Dr DRAGAN BOGETIĆ, naučni savetnik

Institut za savremenu istoriju

Beograd, Trg Nikole Pašića 11, Republika Srbija

dbogetic@gmail.com

originalan naučni rad

UDK: 327.55:005.745(689.4)"1970"

$94: 327(497.1) " 1970 "$

primljeno: 13. septembar 2017.

prihvaćeno: 15 . novembar 2017.

DOI: 10.29362/IST20VEKA.2018.1.BOG.161-178

\title{
DOPRINOS KONFERENCIJE U LUSAKI 1970. INSTITUCIONALIZACIJI SARADNJE NESVRSTANIH ZEMALJA I NJIHOVOM REAKTIVIRANJU U MEĐUNARODNIM ODNOSIMA*
}

APSTRAKT: U članku su analizirani unutrašnji i spoljni problemi koji su doveli do ozbiljne krize nesvrstanosti i stagnacije zajedničkih aktivnosti nesvrstanih zemalja na međunarodnom planu tokom druge polovine 60-ih godina prošlog veka i inicijativa koje su pokrenute u cilju prevazilaženja takvog stanja. Okupljanje lidera nesvrstanih u glavnom gradu Zambije - Lusaki, septembra 1970, predstavljalo je dobru priliku za dogovor o merama koje bi obezbedile kontinuiranu i koordinisanu zajedničku aktivnost nesvrstanih zemalja, čime bi se sprečilo ponovno marginalizovanje tih zemalja u sferi međunarodnih odnosa. Stoga je Samit u Lusaki, zapravo, predstavljao preloman momenat u sklopu procesa institucionalizacije saradnje vanblokovskih država i formiranja Pokreta nesvrstanosti.

KLJUČNE REČI: blokovi, nesvrstane zemlje, Jugoslavija, Zambija, Kaunda, Tito, dekolonizacija, koordinacija, saradnja, Vijetnam, Bliski istok, Daleki istok

Period uoči Konferencije šefova država ili vlada nesvrstanih zemalja u Lusaki obeležen je protivrečnim kretanjima u međunarodnim odnosima, koja su $\mathrm{u}$ velikoj meri davala ton aktivnostima nesvrstanih zemalja. S jedne strane, nastavljena je tendencija popuštanja međublokovske zategnutosti, a sa druge, dolazi do zaoštravanja postojećih antagonizama i rađanja novih, naročito na tlu nerazvijenog dela sveta.

To je, naime, bilo vreme normalizacije i unapređenja odnosa između SR Nemačke i SSSR-a, a samim tim i između dve nemačke države. Rezultat ovakvog obrta bilo je potpisivanje ugovora o odricanju od upotrebe sile između Bona i Moskve, 12. avgusta 1970, a potom i privremeno regulisanje pitanja nemačko-poljske granice posebnim ugovorom između Bona i Varšave, 7. decembra 1970. godine. Moskovskim ugovorom bila je zagarantovana nepovredivost granica, čime je SR

* Rad je deo projekta Srpsko društvo u jugoslovenskoj državi u 20. veku: između demokratije i diktature, (broj 177 016), koji finansira Ministarstvo prosvete, nauke i tehnološkog razvoja Republike Srbije. 
Nemačka konačno priznala granicu na Odri i Nisi kao zapadnu poljsku granicu, ali i granicu između dve nemačke države (de fakto priznanje DR Nemačke). ${ }^{1}$

Uzajamna kooperativnost u odnosima između dve supersile dolazila je do izražaja u njihovim dogovorima o mnogim važnim međunarodnim pitanjima. Ti dogovori su postizani mimo ostalih involviranih međunarodnih aktera. Tako su SAD i SSSR postepeno stvarali zatvoren sistem odnosa između sebe, koji je bio potpuno odvojen od svetskog sistema odnosa i vodio značajnoj marginalizaciji delatnosti Ujedinjenih nacija. Najkarakterističniji primer bio je dogovor ove dve sile o stvaranju kordona vojnih jedinica na granici između Izraela i Ujedinjene Arapske Republike (UAR), koji bi činile isključivo američke i sovjetske trupe. Tako su SAD i SSSR preuzeli ekskluzivno pravo da svojim zajedničkim snagama obezbede održavanje mira na Bliskom istoku. Do tada su Ujedinjene nacije vodile računa da iz ovakvih akcija budu isključeni vojnici velikih sila. To što je ovo pravilo narušeno i Ujedinjene nacije dovedene u poziciju pasivnog posmatrača, najbolje je govorilo o bitno izmenjenom stanju odnosa do tada ljutih rivala u međunarodnim odnosima, ali i o nesumnjivoj složenosti i ograničenosti te vrste detanta. ${ }^{2}$ Pregovori dveju supersila oko ograničenja strateškog naoružanja („Strategic Arms Limitation Talks“ - SALT) nastavljeni su tokom 1970. godine u sklopu dve runde pregovora: jedne u Beču i druge u Helsinkiju. Ovaj pregovarački proces bio je rezultat sazrevanja obostranog zaključka da je dotadašnja trka u naoružanju progutala ogromna sredstva, a nije obezbedila nikakvu prednost, niti unapredila bezbednost, ni jednoj ni drugoj strani. ${ }^{3}$

Međutim, opasna žarišta kriza na područjima nerazvijenog dela sveta u kojima je težište međublokovskog sukoba, doduše, bilo prebačeno sa terena direktne međusobne konfrontacije na teren indirektne konfrontacije, ozbiljno su ugrožavala mir i bezbednost u svetu. Novooslobođene i nesvrstane zemlje bile su izložene oštrim pritiscima bivših metropola, koje su pokušavale da povrate svoje ranije pozicije na tlu Azije i Afrike, izgubljene tokom procesa dekolonizacije.

Pogoršavanje aktuelnog stanja u međunarodnim odnosima tokom druge polovine 60-ih godina bilo je u znaku četiri vojne agresije u koje su direktno ili indirektno bile umešane supersile i njihovi vojni saveznici. To je bilo vreme kada dolazi do američke agresije u Vijetnamu i Dominikanskoj Republici početkom 1965, izraelske agresije na Bliskom istoku juna 1967. i vojne agresije pet zemalja članica Varšavskog pakta u Čehoslovačkoj avgusta 1968.

$\mathrm{S}$ druge strane, nemoć novouspostavljenih režima u nesvrstanim zemljama da na pravi način pristupe razrešenju privrednih problema vodila je stalnoj političkoj nestabilnosti u tim zemljama, a burna unutrašnja politička previranja, opet, ima-

${ }^{1}$ Vladimir Ivanović, Jugoslavija i SR Nemačka 1967-1973 (Beograd: ISI, 2009), 47-49; Keesing's Contemporary Archives, 1970, 23853; Godišnjak Instituta za međunarodnu politiku i privredu. 1970 (Beograd: Institut za međunarodnu politiku i privredu (IMPP), 1971), 91-97.

${ }^{2}$ Lidija Čehulić Vukadinović, Euroatlantizam i suvremeni međunarodni odnosi (Zagreb: Politička kultura, 2010); Godišnjak Instituta za međunarodnu politiku i privredu. 1970.

3 Arhiv Jugoslavije (AJ), Kabinet Predsednika Republike (KPR), I-2/63. Vojni aspekti evropske bezbednosti; Radovan Vukadinović, Evropska sigurnost i suradnja (Zagreb: Globus, 1976); Ljubivoje Aćimović, Problemi bezbednosti i saradnje u Evropi (Beograd: IMPP/Prosveta, 1978). 
la su za posledicu učestale prevrate (Indonezija, Kambodža, Gana, Nigerija). Unutrašnjoj nestabilnosti posebno je doprinosio snažan pritisak moćnih aktera neokolonijalističke i imperijalne politike, kome su permanentno bile izložene novooslobođene zemlje. Stvari su se dodatno komplikovale zbog narastajućih izvora međusobnog sukobljavanja susednih afro-azijskih zemalja (indijsko-pakistanski sukob, sukobi između arapskih zemalja, vijetnamsko-kambodžanski sukob). ${ }^{4}$

Zaokupljenost sopstvenim unutrašnjim problemima i problemima užeg geografskog područja potiskivala je u drugi plan deklarativno iskazanu spremnost za organizovanijim zajedničkim nastupom nesvrstanih $\mathrm{u}$ međunarodnim odnosima radi obezbeđivanja osnovnih premisa vanblokovske politike i otklanjanja žarišta svetskih kriza koja su u velikoj meri predstavljala važna izvorišta pomenutih problema. Tokom perioda koji je nastupio posle Kairske konferencije dolazi do svojevrsne krize i znatne oseke u političkom angažovanju nesvrstanih zemalja u međunarodnim odnosima. ${ }^{5}$

Pa ipak, ovde se nije radilo istovremeno i o krizi same doktrine i nesvrstane spoljnopolitičke orijentacije tih zemalja. One i dalje nisu odustajale od takve međunarodne strategije i generalno su zadržale svoju vanblokovsku poziciju. Načela nesvrstanosti sticala su sve veći broj pobornika među zemljama u područjima u kojima je bio eliminisan kolonijalizam. Sve veći broj novooslobođenih zemalja se opredeljivao za vođenje vanblokovske politike. Problem se ticao realizacije koncepta institucionalizacije saradnje nesvrstanih zemalja i potrebe da se kroz zajednički i organizovan nastup nesvrstanih zemalja obezbedi njihov veći uticaj na aktuelna međunarodna zbivanja, koja su, inače, bila u direktnoj koliziji sa osnovnim političkim premisama njihove spoljne politike. Dakle, kriza se osećala u mogućnostima ponovnog okupljanja nesvrstanih zemalja, u stagnaciji njihove zajedničke aktivnosti i pasiviziranju na širokim područjima Azije i Afrike na kojima je nesvrstanost upravo i izrasla. ${ }^{6}$

Sem toga, problem je bio i u tome što se među nesvrstanima nije iskristalizovao jedinstven stav u pogledu konkretne fizionomije i širine pokreta koji bi obezbeđivao sinhronizovan nastup vanblokovskih zemalja u međunarodnim odnosima. Jedan deo nesvrstanih zemalja, među kojima je Jugoslavija bila najeksponiranija, zalagao se za stvaranje širokog pokreta u koji bi bile uključene sve nesvrstane zemlje i, istovremeno, pokreta koji bi svoju aktivnost usmerio na razrešenje svih relevantnih međunarodnih pitanja koja su opterećivala celokupnu sferu međunarodnih odnosa, a ne samo pitanja vezanih za uži prostor na

${ }^{4}$ Leo Mates, Međunarodni odnosi socijalističke Jugoslavije (Beograd: Nolit, 1976); Radnički i nacionalno-oslobodilački pokreti, tom I, Afrika, Azija, Latinska Amerika, urednik Sulejman Redžepagić (Beograd: Institut za izučavanje radničkog pokreta, 1968).

${ }^{5}$ Lazar Mojsov, „Savremena kriza međunarodnih odnosa i politika i pokret nesvrstanosti“, u: Tito - nesvrstanost - savremenost, Zbornik radova, urednici Bojana Tadić, Vladimir Falatov (Beograd: Memorijalni centar „Josip Broz Tito“, 1988), 175-193; Miroslav Kreačić, „Značaj Konsultativnog sastanka specijalnih predstavnika vlada nesvrstanih za kontinuitet i razvoj pokreta nesvrstanosti“", u: Tito - nesvrstanost - savremenost, 87-93.

${ }^{6}$ Olivera Bogetić i Dragan Bogetić, Nastanak i razvoj pokreta nesvrstanosti (Beograd: Exportpress, 1981). 
kome su se najdrastičnije ispoljavali problemi zemalja Trećeg sveta. Pri tome se polazilo od stanovišta da je svetski mir nedeljiv i da se krizna žarišta iz Evrope u najkraćem mogućem roku mogu preneti na afro-azijski prostor (i obrnuto sa afro-azijskog prostora na Evropu). ${ }^{7}$

U pojedinim nesvrstanim zemljama, pak, javile su se težnje za oživljavanjem regionalnog pokreta afro-azijske solidarnosti kao posebne grupacije novooslobođenih zemalja sa ovog prostora. Protagonisti ove ideje uživali su snažnu podršku NR Kine. Radilo se zapravo o novoj alternativi okupljanja zemalja u razvoju, koja je sama po sebi činila izlišnom ideju o stvaranju široke asocijacije država koja bi okupljala sve nesvrstane zemlje nezavisno od njihovog prostornog određenja. Osnivačka konferencija ovakvog regionalnog pokreta trebalo je da se održi u Alžiru u leto 1965. Međutim, srećna okolnost za protagoniste suprotnog (univerzalnog) koncepta, bila je ta što je pomenuta afroazijska konferencija nešto kasnije odložena zbog državnog udara u Alžiru, da bi zatim, usled organizacionih i političkih teškoća, bila i definitivno otkazana. ${ }^{8}$

U vreme kada je deo afro-azijskih država bio zaokupljen idejom o organizovanju regionalnog samita u Alžiru, u Beogradu je marta 1965. održana Konferencija ambasadora 15 nesvrstanih zemalja povodom otpočinjanja Vijetnamskog rata. Na tom skupu su razmatrane mogućnosti za miroljubivo razrešenje Vijetnamske krize. Stoga je sačinjen i poseban Apel, u kome je osuđena „strana vojna intervencija“" (nije precizirano čija) i u kome su involvirane zemlje pozvane da odmah pristupe „bezuslovnim pregovorima“. Budući da je Apel primljen izuzetno negativno od obe strane u sukobu, ${ }^{9}$ Beogradska konferencija nije ostvarila svoju miroljubivu intenciju, niti doprinela reafirmaciji stava da su zajedničke i organizovane akcije nesvrstanih najsigurnije sredstvo za prevazilaženje aktuelnih žarišta svetskih kriza. ${ }^{10}$ Sasvim suprotno, epilog ove akcije je daleko više išao u prilog prokineski orijentisanom bloku nesvrstanih zemalja, koje su negirale mogućnost miroljubive koegzistencije između „starih“ i „novih snaga“ i zagovarale radikalna sredstva borbe protiv ,istočnog i zapadnog imperijalizma“. ${ }^{11}$

Novi značajan pokušaj, kako bi se učinilo nešto čime bi se prekinula stagnacija aktivnosti nesvrstanih zemalja, predstavljao je trojni sastanak predsednika Tita, Nasera i premijerke Indire Gandi, oktobra 1966. u Nju Delhiju. ${ }^{12}$ To je nesumnjivo bio važan korak u pravcu reafirmacije i ponovnog aktiviranja politike nesvrstanosti. Učesnici Delhijskog sastanka su prvenstveno bili zaokupljeni pitanjem kako da podstaknu ostale protagoniste nesvrstavanja na zajednič-

${ }^{7}$ Dragan Bogetić, "Yugoslavia and Non-Alignment: a Contribution to Overcoming Prejudices and Stereotypes", Annales, Series Historia et Sociologia, let. 24, br. 4 (2014), Koper 2014, 615-624.

${ }^{8}$ Diplomatski arhiv Ministarstva spoljnih poslova Republike Srbije (DA MSP), 1964, str. pov., 872, „Nove snage“ (Indonežanska inicijativa); Momir Stojković, Tito-Nehru-Naser-nastavak $i$ razvoj politike i pokreta nesvrstanosti (Zaječar: „Zaječar“, 1983), 158-159.

${ }^{9}$ DA MSP, 1965, str. pov., f-1, 52 i 22.

${ }^{10}$ DA MSP, 1966, str. pov., f-1, 13, Izvod iz Zapisnika sa sastanka Kolegija DSIP-a održanog 21. II 1966; AJ, KPR, I-5-b, Vijetnam. Predlog za odgovor na Demarš vlade DR Vijetnama.

${ }^{11}$ DA MSP, 1965, str. pov., f-1, 52, Najnoviji razvoj u vezi sa Vijetnamom.

${ }^{12}$ Hronika međunarodnih događaja, 1966 (Beograd: IMPP, 1967), 1107A. 
ku i organizovanu akciju u međunarodnim odnosima, na češće međusobne kontakte i eventualno organizovanje šireg skupa na kome bi se takva strategija mogla detaljnije i konkretnije razraditi. Postignuta je saglasnost da dva predsednika i indijska premijerka zajednički ulože napore u jačanju solidarnosti nesvrstanih zemalja i intenziviranju njihovih bilateralnih i multilateralnih kontakata. ${ }^{13}$

Uprkos svemu tome, sve do pred kraj ovog perioda, odnosno sve do 1969. godine, vidno je bilo opadanje zajedničkih aktivnosti nesvrstanih zemalja. U stavovima i ponašanju nesvrstanih zemalja ispoljavani su pretežno oni elementi koji su vodili njihovom razjedinjavanju. Istovremeno, da izražaja dolazi i ozbiljno nejedinstvo ovih zemalja po pitanju brojnih dilema oko načina prevazilaženja i razrešenja brojnih kriza sa kojima se suočavao Treći svet. Nesvrstane zemlje nisu našle prave odgovore na nove izazove sa kojima su se suočavale. Posle njihovog Samita u Kairu ponavljala se slična situacija kao i posle Beogradskog samita smanjivale su se tenzije između dveju supersila, ali su se otvarala nova žarišta kriza i povećavao pritisak na zemlje u razvoju. Tokom razdoblja koje je nastupilo posle Kairske konferencije, stanje se u tom kontekstu znatno zaoštrilo zbog Vijetnamskog i Arapsko-izraelskog rata. Ta dva rata su predstavljala težak ispit za glavne protagoniste nesvrstane politike, koji oni nisu uspeli da polože. U oba slučaja došlo je do izražaja nejedinstvo nesvrstanih zemalja i nesposobnost da na pravi način efikasno zajedno odreaguju. To je rezultiralo opadanjem interesa, pa i razočaranjem pojedinih zagovornika nesvrstane politike u pogledu svrsishodnosti i delotvornosti ovakve strategije (posebno od strane lidera direktno uključenih država - Egipta, Sirije, Vijetnama, Laosa, Kambodže).$^{14}$

Ispostavilo se da samo smanjenje hladnoratovskih tenzija ne vodi i smanjenju pritiska na nesvrstane zemlje, nego suprotno - vodi povećanju ugrožavanja bezbednosti tih zemalja i broja lokalnih sukoba. U takvoj situaciji obesmišljen je jedan od dotadašnjih prioriteta nesvrstane politike - delatnost koncentrisana na pomirenje suprotstavljenih blokova i akcije koje bi trebalo da ohrabre saradnju dveju supersila. Čak je i samo insistiranje na vanblokovskom karakteru politike nesvrstanosti postajalo sve nepopularnije u pojedinim nesvrstanim zemljama. ${ }^{15}$

Dalje forsiranje akcija nesvrstanih baziranih na staroj političkoj platformi neminovno je vodilo novim neuspesima i novim razočaranjima. Neophodno je bilo tražiti nove puteve, koji bi bili utemeljeni na novim iskustvima, a vodili realizaciji objektivno ostvarljivih ciljeva. U sklopu takvih nastojanja, krajem 60 -ih godina dolazi do novih inicijativa pojedinih protagonista nesvrstane politike, čiji je cilj bilo ponovno okupljanje svih nesvrstanih zemalja i oživljavanje i intenziviranje njihove zajedničke i kontinuirane akcije na međunarodnom planu. Počev od 1969, kada je u Beogradu tokom jula održan Konsultativni sastanak specijalnih predstavnika vlada nesvrstanih zemalja, a septembra iste godine - Ministarski sastanak nesvrstanih u Njujorku, dolazi do važnog obrta u

\footnotetext{
${ }^{13}$ AJ, KPR, I-4-a/6, Trojni sastanak Josipa Broza Tita, Indire Gandi i Gamala Abdela Nasera, Nju Delhi, 20-25. oktobar 1966.

${ }^{14}$ AJ, KPR, I-4-a/8, Položaj i uloga nesvrstanih zemalja; AJ, KPR, I-4-a/9, Informativno-politički materijal.

${ }^{15}$ Isto.
} 
tom pogledu. Od tada se može pratiti ponovna uzlazna linija u aktivnostima koncentrisanim na uspostavljanje tešnje saradnje između nesvrstanih zemalja i održavanje samita na kome bi se obezbedili uslovi da se takva saradnja na određen način institucionalizuje. Na sastancima u Beogradu i Njujorku preovladavala je ocena učesnika da, bez obzira na manja odstupanja, nesvrstane zemlje povezuju isti ciljevi, da imaju slične interne probleme i da njihovu međunarodnu poziciju u mnogo čemu određuju vrlo slične determinante. Stoga je ponovo izražena rešenost ovih zemalja da intenziviraju međusobnu saradnju, ali i da pojačaju svoje zajedničke aktivnosti na širem međunarodnom planu. ${ }^{16}$

Period priprema za novu konferenciju najviših predstavnika nesvrstanih zemalja krajem 60 -ih godina bio je u znaku brojnih bilateralnih kontakata, izjava uticajnih zvaničnika iz ovih zemalja i sastanaka multilateralnog karaktera posvećenih definisanju konkretnih oblika i područja saradnje, ali i pravaca akcije u međunarodnim odnosima. U sklopu ovakvih bilateralnih i multilateralnih kontakata, usredsređenih na ponovno aktiviranje nesvrstanih zemalja, ključni akter bila je nesumnjivo Jugoslavija. ${ }^{17}$ Jedino je ona bila životno zainteresovana za formiranje Pokreta nesvrstanosti, jer je u tome videla dobru priliku da generalno ojača svoju međunarodnu poziciju i na pravi način neutrališe permanentan pritisak Istoka i Zapada, koji je ozbiljno dovodio u pitanje očuvanje njene nacionalne nezavisnosti. Za Jugoslaviju je uključivanje u jednu novu, široku asocijaciju vanblokovskih država, u kojoj bi imala istaknuto mesto, predstavljalo jedinu spoljnopolitičku alternativu koja bi je oslobodila te nezahvalne uloge usamljenog evropskog igrača na tankoj liniji između dvaju oštro suprotstavljenih blokova, gde samo jedan pogrešan korak može dovesti do totalnog debakla. ${ }^{18}$

Početkom 1968 (od 7. januara do 8. februara) Tito je boravio u zvaničnoj, prijateljskoj poseti azijskim i afričkim zemljama. Prilikom posete Avganistanu, Pakistanu, Kambodži, Indiji, Etiopiji i UAR, uporno je isticao potrebu održavanja nove konferencije nesvrstanih zemalja i reaktiviranja zajedničkih akcija tih zemalja. Inicijativa je naišla na pozitivan prijem. Svi njegovi sagovornici su ispoljili gotovo istovetne ocene u pogledu pozadine i ishodišta eskalacija kriza na Bliskom i Dalekom istoku i potrebe da se na širem međunarodnom planu preduzmu energičniji koraci u pravcu eliminisanja kriznih žarišta. U tom kontekstu, Titova ideja o okupljanju svih lidera nesvrstanih zemalja činila im se izuzetno svrsishodnom. ${ }^{19}$

${ }^{16}$ AJ, KPR, I-4-a/7, Konsultativni sastanak predstavnika nesvrstanih zemalja, Beograd, 8-12. jul 1969; DA MSP, PA, 1969, R, f-150, 426 118, Consultative Meeting of Special Government Representatives of Non-Aligned Countries, Belgrade, July 8-12, 1969; AJ, KPR, I-4-a/9, Saopštenje sa Ministarskog sastanka nesvrstanih zemalja, Njujork, 27. septembar 1969; DA MSP, PA, 1969, R, f-152, 446 434, Prva ocena Ministarskog sastanka nesvrstanih zemalja, održanog u Njujorku, 27. septembra 1969; Isto, f-151, 434957.

${ }^{17}$ Tvrtko Jakovina, „Tito's Yugoslavia as the Pivotal State of the Non-Aligned“, u: Tito - viđenja i tumačenja, Zbornik radova, urednica Olga Manojlović Pintar (Beograd: INIS, Arhiv Jugoslavije, 2011), 389-404; AJ, KPR, I-4-a/7, Pregled ocena dosadašnjih reagovanja na inicijativu za sazivanje konferencije na vrhu; Informacija o stavovima učesnica Kairske konferencije nesvrstanih zemalja prema inicijativi za održavanjem nove konferencije.

${ }^{18}$ Dragan Bogetić, ,Jugoslavija u Hladnom ratu“, Istorija 20. veka, god. XXVI, br. 2, (2008), 315-370.

${ }^{19}$ AJ, KPR, I-4-a/7, Stavovi afričkih i arapskih zemalja prema inicijativi za sazivanje konferencije 
Ohrabren podrškom afro-azijskih zemalja, Tito je u proleće 1968. uputio poruke liderima nesvrstanih zemalja - koji su po njegovoj proceni bili zainteresovani za ponovno oživljavanje njihovih zajedničkih aktivnosti - da se pridruže naporima Jugoslavije u pravcu priprema za novi samit nesvrstanih. Sa izuzetkom Alžira, ova Titova inicijativa je naišla na energičnu podršku. ${ }^{20}$

Dve godine kasnije (od 26. januara do 27. februara 1970), Tito je posetio zemlje istočne i severne Afrike, sa ciljem da se, u ponovo zaoštrenoj međunarodnoj situaciji, pripremi program i platforma za buduće sastanke i aktivnosti nesvrstanih zemalja. ${ }^{21} \mathrm{U}$ toku razgovora sa liderima Tanzanije, Zambije, Etiopije, Kenije, Sudana, Egipta i Libije izražen je stav da je novi sastanak na vrhu nesvrstanih zemalja poželjan i koristan, te da bi trebalo da se održi pre XXV jubilarnog zasedanja Generalne skupštine Ujedinjenih nacija, kako bi na tom zasedanju mogle biti donete konkretne odluke o krupnim međunarodnim pitanjima. ${ }^{22}$ Već narednog meseca održan je Pripremni sastanak u Dar es Salamu (Tanzanija). Na njemu je formalno doneta odluka o sazivu Trećeg samita nesvrstanih, usvojen predlog dnevnog reda, utvrđeni kriterijumi za učešće na samitu i vreme i mesto njegovog održavanja. ${ }^{23}$

Treća konferencija šefova država ili vlada nesvrstanih održana je u prestonici Zambije - Lusaki, od 8. do 10. septembra 1970, dakle punih šest godina posle poslednjeg samita nesvrstanih u Kairu, što je ujedno bio i najveći vremenski razmak između dva samita $u$ istoriji politike nesvrstanosti. Taj podatak je, sam po sebi, ukazivao na ozbiljna iskušenja sa kojima se u to vreme suočavala nesvrstana politika. Masovno učešće nesvrstanih zemalja na Samitu (54 punopravne učesnice i 10 posmatrača), govorilo je, pak, o tome da su nesvrstani i dalje bili zainteresovani za postizanje određenog dogovora o merama koje mogu obezbediti uslove za usaglašenu i kontinuiranu zajedničku akciju na širem međunarodnom planu.

Činjenica, međutim, da na Samitu u Lusaki nisu prisustvovali jedan od glavnih protagonista nesvrstane politike, egipatski predsednik Naser, ni lideri ostalih arapskih zemalja (sa izuzetkom Sudana) - ukazivala je na ozbiljne rezerve $\mathrm{u}$ arapskom svetu o pitanju dalje svrsishodnosti i delotvornosti nesvrstane politike. ${ }^{24}$ Ovakva promena stava prema politici nesvrstavanja usledila je posle katas-

nesvrstanih; Pregled ocena dosadašnjih reagovanja na inicijativu za sazivanje konferencije na vrhu; Zvonko Štaubringer, Maršal mira (Zagreb: Globus, 1980); Đorđe Radenković, Tito: susreti sa državnicima sveta (Beograd: Mladost, 1975); Blažo Mandić, Tito u dijalogu sa svetom (Novi Sad: Mir/Prometej, 2005).

20 AJ, KPR, I-4-a/7, Najnoviji momenti u vezi sa jugoslovenskom inicijativom za održavanjem konferencije nesvrstanih na vrhu; AJ, KPR, I-4-a/8, Bilans aktivnosti nesvrstanih zemalja od inicijative predsednika Tita za sazivanje nove konferencije nesvrstanih.

${ }^{21}$ Isto; AJ, KPR, I-4-a/7, Priprema Sastanka.

${ }^{22}$ AJ, KPR, I-4-a/7, Priprema Sastanka; Z. Štaubringer, $n$. $d$.; Đ. Radenković, $n$. $d$.; B. Mandić, $n$. $d$.

${ }^{23}$ AJ, KPR, I-4-a/8, Pripremni sastanak za Treću konferenciju neangažovanih zemalja, Dar es Salam, 13-17. april 1970; DA MSP, PA, 1970, R, f-239, 423 040, Opšti izveštaj o Pripremnom sastanku u Dar es Salamu od 13. do 17. aprila 1970.

${ }^{24}$ Tito je, po povratku u Beograd, Naserovo odbijanje da prisustvuje Samitu u Lusaki okarakterisao kao „tendenciju miniranja, težnju da se na neki način oslabi efekat skupa nesvrstanih“, kao „neki pritisak odnekuda, da se pomoću Nasera, minira naš skup, da ne uspije“. Jugoslovenski 
trofalnog poraza Egipta, Sirije i Jordana u ratu sa Izraelom 1967. godine. Sve frustracije koje su posle ovog rata bile prisutne među Arapima najeksplicitnije su dolazile do izražaja u izjavama egipatskog predsednika Nasera. On je smatrao da je Egipat, upravo zbog toga što je vodio nesvrstanu politiku - umesto da uspostavi savezničke odnose sa SSSR-om - postao žrtva agresije Izraela. U tom kontekstu je rezignirano isticao da „nesvrstane politike više nema“ i najavio da će „UAR preispitati svoje stavove“. Zvanično je ponudio Sovjetima da kao svoje baze koriste egipatske luke „počev od Aleksandrije do Crvenog mora“. ${ }^{25} \mathrm{~S}$ obzirom na ogroman Naserov autoritet, njegova nespremnost da prisustvuje Samitu u Lusaki (formalno obrazložena obavezama proizašlim iz ponovnog zaoštravanja u egipatsko-izraelskim odnosima), rezultirala je time da su i ostale arapske zemlje u Lusaki bile predstavljene isključivo ministrima inostranih poslova. ${ }^{26}$

Pored Nasera, uočljivo je bilo i odsustvo lidera još jedne zemlje koja se među prvima opredelila za nesvrstanost i aktivnog učesnika Beogradskog i Kairskog samita - Burme. Ta zemlja je sve više ispoljavala izrazito rezervisan stav prema mogućnostima zajedničke akcije nesvrstanih i negirala svrsishodnost bilo kakvog oblika trajnijeg povezivanja nesvrstanih zemalja. Burmansko rukovodstvo je pri tome polazilo od stanovišta da bi to samo povećalo razjedinjenost među nesvrstanim zemljama, odnosno da ne bi doprinelo harmonizaciji njihovih odnosa. Sem toga, povezivanje nesvrstanih zemalja bi, $u$ duhu ovakvog tumačenja, dodatno pojačalo njihovu konfrontaciju sa blokovima. Ovakvo stanovište obrazložio je burmanski predstavnik na Konsultativnom sastanku nesvrstanih u Beogradu, ${ }^{27}$ a polazeći od takvog stava Burma uopšte nije prisustvovala Samitu u Lusaki. ${ }^{28}$

Najveći porast zastupljenosti na Samitu u Lusaki zabeležile su afričke zemlje. Takav trend može se objasniti pre svega time da je proces dekolonizacije u ovom periodu posebno zapljusnuo ovaj kontinent, naročito njegov južni deo. U odnosu na prethodna dva samita povećao se i broj latinoameričkih učesnika. Sada su, pored Kube, u svojstvu punopravnih učesnika prisustvovale i tri

predsednik je procenio da je Naserovo odsustvo delovalo „razočaravajuće“ na mnoge učesnike Samita, ali da su ga oni istovremeno zbog toga i „osuđivali“ i da je zato Naser „izgubio svoj renome konsekventnosti“". Tito je stalno potencirao da se tu radi o „pritisku izvana“ $i$ naglašavao da ga „muči pitanje, ko je stajao iza ove diverzije na kraju“. Bilo je prilično očigledno da pri tome misli na Sovjete. To se videlo i iz primedbe na račun Nasera, koja je potom usledila: „A on može da provede 15 dana u Moskvi, a ne nađe za shodno da tu (u Lusaku - D. B.) dođe“. Još eksplicitnije je ovaj nagoveštaj izražen nešto kasnije, na sednici Predsedništva SKJ, 4. decembra 1970. Obrazlažući potrebu da što pre ode u Kairo (gde inače krajem septembra nije prisustvovao sahrani Nasera, zbog posete Niksona Jugoslaviji), Tito je objasnio da mora otići u Egipat ,jer se tamo radi punom parom i to, moram da kažem, od strane jedne velike sile da nas se potpuno eliminiše". O kojoj se sili radi nije bilo teško pogoditi, jer je Tito potom napomenuo da „ne treba da gledamo mirno da nas, recimo, Sovjetski Savez tamo optužuje za nešto što nije tačno“. AJ, KPR, II-3-a1/100, Izlaganje predsednika Tita na sednici Predsedništva SKJ u Zagrebu, 18. septembar 1970; Isto, Izlaganje predsednika Tita na Sednici Predsedništva SKJ 4. decembra 1970.

${ }^{25}$ D. Bogetić, Jugoslovensko-američki odnosi 1961-1971, 221-225.

${ }^{26}$ DA MSP, PA, 1970, R, f-240, 432 028, Pregled nivoa učešća nesvrstanih zemalja na Konferenciji u Lusaki; Arapske zemlje i Konferencija nesvrstanih.

${ }^{27}$ M. Kreačić, n. d., 87-93.

${ }^{28}$ AJ, KPR, I-4-a/9, Informativno-politički materijal. Dokumentacija za Konferenciju na vrhu. Burma. 
države karipskog područja: Trinidad i Tobago, Jamajka i Gvajana. Od evropskih država i dalje su u punopravnom svojstvu bile zastupljene samo Jugoslavija i Kipar, a u svojstvu gosta prisustvovale su Austrija i Finska. ${ }^{29}$

Rad Konferencije odvijao se paralelno na tri koloseka: na sastancima ministara inostranih poslova, u Plenumu, na kome je vođena generalna debata i u radnim komitetima - Političkom i Ekonomskom u kojima su pripremani tekstovi završnih dokumenata. ${ }^{30}$ Konferencija je počela sastankom ministara inostranih poslova na kome su obavljene osnovne organizacione pripreme, finalizovan tekst dnevnog reda i rešena dva preostala sporna pitanja - učešće Privremene revolucionarne vlade Južnog Vijetnama i predstavništvo Kambodže. ${ }^{31}$

Dnevni red nije značajnije izmenjen u odnosu na predlog formulisan na Pripremnom sastanku u Dar es Salamu. Jedina bitnija izmena bila je izdvajanje problema saradnje među nesvrstanima kao posebne (pete) tačke dnevnog reda, što je ukazivalo na novu važnu preokupaciju nesvrstanih zemalja u savremenim uslovima. ${ }^{32}$ Budući da su se pojedine tačke dnevnog reda u mnogo čemu poklapale i preklapale, već na samom početku su stvoreni uslovi za nepotrebno razvodnjavanje diskusije i učestalo ponovno razmatranje istih pitanja. To je prvenstveno dolazilo do izražaja u radnim komitetima, čiji je zadatak bio pripremanje nacrta završnih dokumenata. Tu su često ignorisana pitanja formulisana u okviru dnevnog reda i prioritet davan onim pitanjima koja su sami članovi tih radnih tela ocenjivali kao najznačajnija za uspešan ishod tog skupa i za realizaciju užih sopstvenih nacionalnih programskih ciljeva i interesa. Stoga je, kasnije, i došlo do usvajanja čitavog niza završnih dokumenata - dve deklaracije i 14 posebnih rezolucija. Poseban problem je bio u tome što su se pojedini od ovih dokumenata odnosili na neka marginalna pitanja, bez većeg opšteg značaja za sve učesnike Samita, kao što je, na primer, bio slučaj sa Rezolucijom o korišćenju morskog dna i Rezolucijom o pitanju ilegalnog hapšenja i držanja u zatvoru dvojice alžirskih građana od strane izraelskih vlasti. ${ }^{33}$

Za razliku od diskusije u radnim komitetima, koja je bila vrlo burna i povremeno opterećena ozbiljnim nesuglasicama, u govorima šefova delegacija tokom plenarnog zasedanja, koje se uporedo odvijalo, nije bilo oštrijih polemičkih tonova. U njima je ispoljen visok stepen jedinstva u stavovima i nastojanje da se racionalno procene mogućnosti i područja zajedničke akcije nesvrstanih i da se stvori što konstruktivniji program ove aktivnosti. Pri tome, akcenat nije stavljan na opšte svetske probleme i na šire interese nesvrstanih u tom kontekstu, već isključivo na probleme sa kojima su se suočavale pojedine afričke zemlje (prvenstveno one na jugu ovog kontinenta) i na krizna žarišta na Bliskom i Dalekom

${ }^{29}$ DA MSP, PA, 1970, R, f-241, 432 028, Dokumentacija za Konferenciju na vrhu.

${ }^{30}$ Dokumenti Konferencije i izvodi iz izlaganja učesnika u Generalnoj debati objavljeni su u Međunarodnoj politici (1970), br. 491 i 493.

${ }^{31}$ AJ, KPR, I-4-a/9, Ministarski sastanak.

32 AJ, KPR, I-4-a/9, Izveštaj o Trećoj konferenciji šefova država ili vlada nesvrstanih zemalja, Lusaka, 8-10. septembar 1970.

${ }^{33}$ AJ, KPR, I-4-a/9, Rad u komitetima; Bilteni političkih informacija o radu Konferencije; Neka razmatranja o programu i aktivnostima nesvrstanih zemalja posle Lusake. 
istoku. Sve ostalo je dobilo drugorazredan tretman, posebno problemi koji su se ticali latinoameričkog i evropskog prostora. Jugoslovenski zvaničnici, koji su bili glavni inicijatori ovog skupa, ispoljavali su određeno nezadovoljstvo zbog takvog kursa Konferencije. U razgovoru sa Miltonom Oboteom, premijerom Ugande, Tito mu se požalio na aktuelan tok debate: „Slušajući govore, izgleda da se u svemu slažemo. Pitanje je, da li je to stvarno tako“. U svom završnom govoru, prilikom zatvaranja Konferencije, jugoslovenski predsednik je upozorio da je posle završetka Samita „,neophodno nastaviti akciju“, jer „ovde nisu donete konkretne mere i odluke u tom pravcu, ali se ne bi smjelo dozvoliti da ponovo dođe do takvog vakuma, kao između Kairske i ove, Treće konferencije“..$^{34}$

Centralno pitanje, dakle, koje je dominiralo u generalnoj debati bilo je vezano za probleme kolonijalizma, rasizma i aparthejda. Ovaj kompleks problema je bio naročito aktuelan jer je za većinu afričkih zemalja (koje su, inače, brojčano bile najzastupljenije na Samitu u Lusaki) predstavljao najozbiljniju prepreku za nacionalnu i političku emancipaciju. Zato je i doneta odluka da se Konferencija održi upravo u glavnom gradu Zambije, zemlje koja je locirana na tom osetljivom području. Granice Zambije, naime, protezale su se duž teritorije Rodezije i portugalskih kolonija Angole i Mozambika, što je često ugrožavalo i njen teritorijalni integritet.

Drugi razlog koji je davao poseban značaj navedenim problemima bio je taj što je većina zemalja učesnica bila iz Afrike i imala zajednički problem - dekolonizaciju juga kontinenta. Stoga su najoštrije osude sa Konferencije u Lusaki bile upućene rasističkim i kolonijalnim režimima u Južnoj Africi. Oni su okarakterisani kao „mrlje na savesti čovečanstva“ i ozbiljna opasnost po međunarodni mir i bezbednost. Ovakva ocena je rezultirala odlukom nesvrstanih zemalja da stave embargo na trgovinu sa Južnoafričkom Republikom i Rodezijom (kao i na trgovinu sa Portugalijom), da prekinu diplomatske i druge odnose sa ovim državama, zabrane pristupanja brodova i uskrate sve pogodnosti avionskog saobraćaja i pruže punu podršku oslobodilačkim pokretima u ovim zemljama preko Organizacije afričkog jedinstva. U vezi sa ovim problemom usvojeno je čak pet posebnih rezolucija. ${ }^{35}$

Pored ove glavne preokupacije zemalja „,crne Afrike“, arapske zemlje su, pak, bile zaokupljene prvenstveno krizom na Bliskom istoku i izraelskom agresijom. Budući da ove zemlje nisu u Lusaki bile zastupljene svojim liderima, ova problematika je, iako predmet opširnog izlaganja ogromne većine učesnika Konferencije, zauzela drugo mesto po svom značaju. Kao i u vezi sa prethodnim pitanjem, i o ovom pitanju je postignuta puna saglasnost svih učesnika: da je jedini put rešavanja bliskoistočne krize - hitno, potpuno i bezuslovno povlačenje svih stranih trupa sa okupiranih arapskih teritorija, kako bi se omogućilo

${ }^{34}$ AJ, KPR, I-4-a/9, Zabeleška o razgovoru Predsednika Republike sa premijerom Ugande, Miltonom Oboteom, 9. septembar 1970; AJ, KPR, I-4-a/9, Popodnevna sednica (Bilten političkih informacija, br. 7, Lusaka, 10. septembra 1970).

${ }^{35}$ AJ, KPR, I-4-a/9, Izveštaj o Trećoj konferenciji šefova država ili vlada nesvrstanih zemalja; Opšta rezolucija o dekolonizaciji; Rezolucija o aparthejdu i rasnoj diskriminaciji; Rezolucija o portugalskim kolonijama (Angola, Mozambik i Gvineja-Bisao); Rezolucija o Namibiji; Rezolucija o Zimbabveu. 
ostvarivanje prava Arapa na samoopredeljenje bez mešanja sa strane. Bezrezervna podrška je pružena i borbi naroda Palestine za legitimna prava i ,povraćaj okupirane teritorije“. Jedan broj zemalja, pre svega arapskih, založio se da se u okviru OUN pokrene postupak za uvođenje sankcija Izraelu u slučaju da i dalje bojkotuje odluke ove svetske organizacije. Ovaj zahtev je, u nešto ublaženom obliku, formulisan u završnim dokumentima Konferencije. ${ }^{36}$

Sve učestalija praksa mešanja velikih sila u unutrašnje poslove drugih država i upotreba sile u međunarodnim odnosima oštro je osuđena u Lusaki i u okviru debate o eskalaciji sukoba u Jugoistočnoj Aziji. I u ovom slučaju upućene su brojne osude na račun politike SAD i zahtevi da ova sila povuče svoje trupe iz Indokine, kako bi se obezbedili uslovi za okončanje rata. Međutim, različita gledišta o konkretnim merama za razrešenje ove krize - koja su odražavala različite ocene učesnika Konferencije u Lusaki o ovom problemu i njihov različit odnos prema zemljama angažovanim u ovom sukobu (posebno prema Kini) - onemogućila su formulisanje konkretnih predloga o ovom pitanju u završnim dokumentima. Umesto toga, sve se svelo na načelne zajedničke stavove o bezrezervnoj ,podršci narodima Jugoistočne Azije u njihovoj herojskoj borbi koju i dalje vode za svoju slobodu i nezavisnost" i o podršci nastojanjima „podeljenih naroda da ostvare svoje jedinstvo“ i da „sami odlučuju o svojoj sudbini, bez stranog mešanja i bez stranog vojnog prisustva“ “ 37

Različit odnos zemalja-učesnica Samita u Lusaki prema glavnim akterima indokineske krize generisao je ozbiljno razmimoilaženje nesvrstanih zemalja oko dva izuzetno važna organizaciona pitanja, čije razrešenje je trebalo da pokaže koliko su zapravo nesvrstane zemlje dosledne u svojoj borbi za realizaciju proklamovanih načela miroljubive koegzistencije. Radilo se o pitanju učešća predstavnika Privremene revolucionarne vlade Južnog Vijetnama na Konferenciji i dilemi oko toga ko treba da predstavlja Kambodžu posle državnog udara u toj zemlji - zvanični premijer Lon Nol ili svrgnuti lider Norodom Sihanuk. Ova dva pitanja su i na prethodnim skupovima nesvrstanih predstavljala ozbiljan izvor nesuglasica i dovodila u pitanje sam ishod tih skupova. U suštini, bez adekvatnog razrešenja dileme kakav status na sastancima nesvrstanih treba da imaju protagonisti politike nesvrstanosti koji su se upravo zbog ovakvog opredeljenja suočavali sa dramatičnim iskušenjima - teško se moglo govoriti o doslednosti ostalih aktera nesvrstane politike. Međutim, s obzirom na polovičan uspeh u razrešenju tog delikatnog problema, čini se da nesvrstani nisu u potpunosti sa uspehom položili ovaj važan ispit. ${ }^{38}$

Na Samitu u Lusaki donete su kompromisne odluke: da Privremena vlada Južnog Vijetnama sudeluje u radu skupa kao posmatrač, a da niko ne zauzme

${ }^{36}$ DA MSP, PA, 1970, R, f-242, 435 836, Izveštaj o Trećoj konferenciji šefova država ili vlada nesvrstanih zemalja; AJ, KPR, I-4-a/9, Rezolucija o Bliskom istoku, Rezolucija o izraelskoj agresiji na Liban.

${ }^{37}$ AJ, KPR, I-4-a/9, Izveštaj o Trećoj konferenciji šefova država ili vlada nesvrstanih zemalja; Rezolucija o Jugoistočnoj Aziji; Deklaracija o miru, nezavisnosti, razvoju, saradnji i demokratizaciji međunarodnih odnosa.

${ }^{38}$ DA MSP, PA, 1970, R, f-241, 432 028, Dokumentacija za Konferenciju na vrhu. 
mesto predstavnika Kambodže (ni Lon Nol, ni Norodom Sihanuk). Najveći deo učesnika Samita je smatrao da je ovakvim odlukama pokazao doslednost u bezrezervnoj podršci narodima koji se bore za nacionalnu nezavisnost i principijelnost $\mathrm{u}$ sprovođenju izvornih principa nesvrstanosti. ${ }^{39}$ Polazilo se od rezona da je Vijetnamcima učinjen ustupak, jer je na samitima nesvrstanih do tada bila praksa da učestvuju samo predstavnici vlada suverenih država. Što se, pak, tiče Kambodže, učesnici Samita su smatrali da je sprečavanjem učešća Lon Nola na Konferenciji - dakle, onemogućavanjem prisustva legalnom predstavniku Kambodže ${ }^{40}$ - učinjena velika usluga Sihanuku (iako mu nije dozvoljeno da i sam učestvuje na tom skupu). Doduše, bilo je i suprotnih mišljenja. Kubanski ministar inostranih poslova okarakterisao je takve odluke kao „sramotne“ i kao „zloban udarac principima nesvrstavanja“. ${ }^{41}$ Tito je, po povratku u Jugoslaviju, na sednici Predsedništva SKJ, ovakav epilog ocenio kao „uspeh“, mada je i sam napomenuo da se moglo postići više „da smo malo više zapeli“, ali da se strahovalo „da ne bude suviše velike opozicije, da ne dođe do nekog rascjepa; bilo je tu malo i oportunističkog““ ${ }^{42}$ Naime, pre početka Konferencije većina učesnika je strahovala da će zbog značajnih pritisaka velikih sila doći do ozbiljnih podela među nesvrstanima oko ovih pitanja, da će to paralisati rad Samita i naneti ozbiljnu štetu akterima politike nesvrstavanja. Sam izostanak konsenzusa učesnika Konferencije oko ovih pitanja nesumnjivo bi doprineo i tome da se zada ozbiljan diplomatski udarac i Privremenoj vladi Južnog Vijetnama, i svrgnutom predsedniku Sihanuku. To se, ipak, nije desilo. Sihanuk, ali i ministarka inostranih poslova Južnog Vijetnama, Nguen Ti Bin, izrazili su svoje zadovoljstvo ishodom ove delikatne bitke, koja je dala značajan ton Konferenciji u Lusaki. ${ }^{43}$

Generalno posmatrano, tokom rada Konferencije dolazio je do izražaja prenaglašen afrički i antikolonijalni akcenat, što je nailazilo na negativnu reakciju zvaničnika jedine dve evropske države koje su prisustvovale u punopravnom svojstvu - Kipra i Jugoslavije. Kiparski predsednik Makarios je bio jedan od retkih koji je akcenat u svom govoru stavio upravo na zbivanja u Evropi, ali potencirajući pri tome uglavnom probleme sa kojima se suočavao Kipar u borbi za očuvanje svog suvereniteta i teritorijalnog integriteta. Jugoslovenski ministar inostranih poslova Mirko Tepavac je, neposredno posle završetka Samita u Lusaki, ukazivao na to „da nije istaknut adekvatan značaj nesvrstanosti u odnosu na ostale delove sveta", naglašavajući da pre svega misli na Latinsku Ameriku i Evropu. Josip Đerđa, koji je inače u pravom smislu reči bio idejni kreator jugoslovenskog koncepta nesvrstanosti i koji je kao istaknuti član jugoslovenske delegacije aktivno učestvovao u radu Konferencije, isticao je svoje nezadovolj-

${ }^{39}$ AJ, KPR, I-4-a/9, Bilteni političkih informacija o radu Konferencije.

${ }^{40} \mathrm{Za}$ učešće Sihanuka na Konferenciji izjasnilo se 17 delegacija, za Lon Nola - samo 7, a za opciju da niko ne bude zastupljen - 15 delegacija. Ostale zemlje su se držale neutralno i nisu glasale. Bilten političkih informacija, br. 2, Lusaka, 7. septembar 1970.

${ }^{41}$ AJ, KPR, I-4-a/9, Nastavak generalne debate (Bilten politickih informacija, br. 6, Lusaka, 10.9.1970).

42 AJ, KPR, II-3-a-1/100, Izlaganje predsednika Tita na sednici Predsedništva SKJ u Zagrebu, 18.9.1970.

${ }^{43}$ AJ, KPR, I-4-a/9, Izveštaj o Trećoj konferenciji šefova država ili vlada nesvrstanih zemalja. 
stvo što je skup u Lusaki suviše vezao nesvrstanost za Afriku na šta je, pored ostaloga, ukazivala i sama činjenica ,da su samo tri-četiri govornika pomenula značajne evropske događaje... Nije se osetio svestan i jači napor da koncepcija nesvrstanosti postane univerzalna“. ${ }^{44}$

Do koje mere je Evropa bila „neinteresantna“ afro-azijskim nesvrstanim zemljama, moglo se uočiti i kroz činjenicu da niko od njihovih predstavnika u Lusaki nije našao za shodno da u sklopu svoje ocene ključnih međunarodnih događaja koji su ugrožavali svetski mir i bezbednost uopšte pomene sovjetsku vojnu intervenciju u Čehoslovačkoj, avgusta 1968. Iako se radilo o otvorenom aktu agresije na jednu suverenu državu - ni u jednom dokumentu Konferencije on nije ni pomenut, a kamoli osuđen od nesvrstanih zemalja. Doduše, razlog tog nepominjanja treba tražiti i u već uobičajenoj nesklonosti većine nesvrstanih zemalja da oštro reaguju na sovjetski intervencionizam, kako su to sa velikim žarom činile kada su u pitanju Amerikanci. Tito je, čak, kasnije otvoreno izražavao svoje zadovoljstvo zbog toga što „niko nije pominjao Ruse“ i „niko ih nije napadao“. „Svi su znali da je to škakljiva stvar i da je nivo Konferencije takav, da se ne treba vraćati na ono što je bilo, na intervenciju u Čehoslovačkoj i zbivanja u njoj"“. ${ }^{5}$

Nesklonost afro-azijskih zemalja da se bave evropskim problemima sama po sebi je predstavljala problem. To je posebno došlo do izražaja na samom kraju Konferencije u Lusaki tokom oštre konfrontacije između Kipra i arapskih zemalja, koja je ozbiljno dovela u pitanje uspešan ishod skupa. Arapske zemlje, naime, odlučno su odbacivale zahtev Makariosa da se usvoji posebna rezolucija o Kipru, u kojoj bi figurisao pasus u kome se podržava nedeljivost, teritorijalna jedinstvenost i teritorijalni integritet Kipra (što je bilo u koliziji sa dugoročnim ciljem turske zajednice na Kipru za formiranje dveju nacionalno nezavisnih federativnih država na tom prostoru). ${ }^{46}$ Zbog ovakvog stava arapskih zemalja, Makarios je odlučio da napusti Samit i da ne potpiše nijedan od završnih dokumenata. Šefovi delegacija arapskih zemalja su, opet, pripretili da će u slučaju da se izađe u susret Makariosu objaviti oštro protesno pismo turske zajednice na Kipru, ${ }^{47}$ koje bi nesumnjivo dovelo do produbljivanja nesuglasica $\mathrm{i}$ konfrontacije učesnika Samita. Indijska premijerka Indira Gandi je zbog takvog negativnog obrta bila prinuđena da prekine završnu sednicu kojom je predseda-

${ }^{44}$ AJ, KPR, I-4-a/9, Bilteni političkih informacija o radu Konferencije; Izvod iz beleške o razgovorima članova jugoslovenske delegacije po završetku Konferencije u Lusaki, 10. septembra 1970.

${ }^{45}$ AJ, KPR, II-3-a-1/100, Izlaganje predsednika Tita na sednici Predsedništva SKJ u Zagrebu, 18. septembar 1970.

${ }^{46}$ DA MSP, PA, 1970, R, f-241, 432 028, Arapske zemlje i Konferencija nesvrstanih.

${ }^{47}$ Pripadnici turske zajednice na Kipru su protestovali zbog toga što progrčki nastrojene kiparske vlasti ne vode računa o etničkim i nacionalnim posebnostima turske manjine na tom ostrvu, odnosno ne vode računa o dvonacionalnom sastavu stanovništva i ravnopravnosti grčke i turske zajednice. To je bilo vreme kada Makarios nije uspevao da se odlučnije suprotstavi pritiscima pristalica grčke vojne hunte i ilegalnim akcijama Atine čiji je konačan cilj bio priključenje Kipra Grčkoj. Dragan Bogetić, „Kiparska kriza 1974. i pogoršanje jugoslovensko-američkih odnosa“, Tokovi istorije, br. 3, (2014), 111-129. 
vala i obrati se Titu za pomoć. Jugoslovenski predsednik je morao preuzeti nezahvalnu ulogu posrednika između sukobljenih strana. Zahvaljujući autoritetu koji je uživao u arapskom svetu, uspeo je da ubedi Makariosove oponente da očuvanje nacionalne nezavisnosti i teritorijalnog integriteta Kipra predstavlja jedini put koji vodi očuvanju kiparske vanblokovske pozicije i da bi u suprotnom ova ostrvska zemlja, preko Grčke i Turske, postala deo NATO struktura i važna američka i britanska vojna baza na Mediteranu. Time bi se dodatno oslabila strateška pozicija arapskih zemalja na Bliskom istoku, a ohrabrile izraelske teritorijalne pretenzije na tom prostoru. Posle više uzastopnih susreta sa Titom, sa arapske strane je obećano da neće biti protivljenja usvajanju Rezolucije o Kipru, ali uz dva uslova: da im se dozvoli da oko toga izraze svoje rezerve i da u tom tekstu figuriše i dodatak o obaveznoj zaštiti prava nacionalnih manjina. Pošto je Tito potom ubedio Makariosa da prihvati arapske uslove, usvojen je tekst Rezolucije o Kipru koji se svodio samo na jednu rečenicu. ${ }^{48}$

Tokom generalne debate i rasprava u radnim komitetima posebna pažnja poklonjena je i kompleksu svetskih ekonomskih problema, pitanju ekonomskog razvoja nesvrstanih zemalja, njihovog neravnopravnog položaja u sferi međunarodnih ekonomskih odnosa i sve većem jazu između ovih zemalja i razvijenih zemalja. Ova pitanja su dala ton i završnim dokumentima Konferencije - Deklaraciji o miru, nezavisnosti, razvoju, saradnji i demokratizaciji međunarodnih odnosa, Deklaraciji o nesvrstavanju i ekonomskom progresu i nizu usvojenih rezolucija. U Deklaraciji o nesvrstavanju i ekonomskom progresu razrađen je plan preduzimanja čitavog niza mera radi jačanja ekonomskog položaja zemalja u razvoju. Zemlje učesnice su izrazile zabrinutost zbog ubrzanog produbljivanja jaza između privreda bogatih i privreda siromašnih nacija, što je ocenjeno kao pretnja nezavisnosti zemalja u razvoju i međunarodnom miru i bezbednosti. Konstatovano je da ove negativne tendencije isključuju zemlje u razvoju iz matice svetskog ekonomskog života i anuliraju njihova nastojanja da učestvuju u savremenom progresu. Priliv finansijskih sredstava (izražen procentom ukupnog nacionalnog dohotka), iz razvijenih zemalja u zemlje u razvoju je opao, a priliv finansijskih sredstava iz zemalja $u$ razvoju $u$ razvijene zemlje povećao se isplatama $u$ vidu dugova, dividendi, korišćenja licenci, finansijskih i komercijalnih usluga. ${ }^{49}$

Da bi se zaustavio proces produbljivanja i zaoštravanja suprotnosti u razvoju svetske privrede, nesvrstane zemlje su predložile energičnu akciju koja bi se uglavnom vodila na dva koloseka. Prvi kolosek bi uključivao niz mera međusobne

${ }^{48}$ AJ, KPR, I-4-a/9, Informativno-politički materijal; „Bilten političkih informacija o radu Konferencije“, br. 7; Zabeleška o razgovoru Predsednika Republike sa predsednikom vlade Indije, Indirom Gandi, 9. septembra 1970; Zabeleška o razgovoru Predsednika Republike sa predsednikom Republike Sudana, Gafar Mohamed Nimeirijem, 10. septembra 1970; Zabeleška o razgovoru Predsednika Republike sa predsednikom Kipra, arhiepiskopom Makariosom, 10. septembra 1970; AJ, KPR, II-3-a-1/100, Izlaganje predsednika Tita na sednici Predsedništva SKJ u Zagrebu, 18. septembar 1970.

${ }^{49}$ AJ, KPR, I-4-a/9. Podsetnik o ekonomskom položaju i uslovima za razvoj zemalja u razvoju; Deklaraciji o miru, nezavisnosti, razvoju, saradnji i demokratizaciji međunarodnih odnosa $i$ Deklaraciji o nesvrstavanju i ekonomskom progresu; Izveštaj o Trećoj konferenciji. 
saradnje i oslanjanja na sopstvene snage nesvrstanih i drugih zemalja u razvoju. Drugi nivo odnosio bi se na delatnost Ujedinjenih nacija na ublažavanju nepovoljnih međunarodnih ekonomskih trendova i poboljšanju položaja zemalja u razvoju. ${ }^{50}$

$\mathrm{Pa}$ ipak, čini se da je glavnu tekovinu Samita u Lusaki predstavljalo nastojanje da se racionalno procene mogućnosti i područja zajedničke akcije nesvrstanih i da se stvori što konstruktivniji program ove aktivnosti. U tom kontekstu, ključno je bilo pitanje koje se često moglo čuti: „Šta će biti posle Konferencije u Lusaki?“, odnosno „Kako sprečiti ponovnu stagnaciju zajedničkih aktivnosti nesvrstanih zemalja posle Lusake?“‘. Dotadašnja iskustva su pokazala da samiti nesvrstanih nisu bili delotvorni $\mathrm{i}$ da nisu rezultirali većim efektom $u$ sferi međunarodnih odnosa i na planu unapređenja međusobnih bilateralnih odnosa. Posle njih nastupali su ,vakuum“ i stagnacija zajedničkih aktivnosti. ${ }^{51}$

Stoga su u Lusaki česte bile opaske, poput one koju je izrekao kubanski ministar inostranih poslova Raul Roa Garsia, „da se sa reči pređe na dela“ i da Konferencija ,pokrene konkretne akcije, jer će završiti u oblacima reči“ 52 Tito je upravo stoga, tokom brojnih razgovora sa učesnicima Samita, stalno pokretao pitanje „kako obezbediti kontinuirane zajedničke aktivnosti nesvrstanih zemalja posle Lusake“. Takav prilaz je uglavnom nailazio na veću ili manju podršku ostalih učesnika Konferencije, koji su bili saglasni u tome da snaga nesvrstanih leži u njihovom jedinstvu. ${ }^{53} \mathrm{U}$ tom smislu, kiparski predsednik Makarios je isticao da „usamljeni glas malih zemalja može da bude ignorisan. Ali, ako budemo jedinstveni bićemo snažni i neće biti moguće olako prelaziti preko naših zahteva“" Alžirski ministar inostranih poslova Buteflika je upozoravao predstavnike nesvrstanih zemalja da u slučaju ,da je njihovo jedinstvo bilo veće - ne bi bio toliki pritisak na njih“ i da ,nesvrstanost mora biti dinamična i aktivna“. 54

Predlagane su različite forme institucionalizacije saradnje nesvrstanih zemalja. Predsednik Zambije Kaunda je predložio osnivanje ,,adekvatne mašinerije za koordinaciju aktivnosti nesvrstanih“. Predsednik Ugande Milton Obote je sugerisao osnivanje Stalnog komiteta predstavnika vlada nesvrstanih zemalja, koji bi bio izabran na principu geografske raspodele i koji bi pomagao generalnom sekretaru u radu. Tu ideju podržao je i predstavnik Togoa. Gvineja je predložila osnivanje sekretarijata, a Somalija - biroa za vezu u glavnom gradu zemlje-domaćina poslednje konferencije, koji bi osiguravao kontinuitet aktivnosti do narednog skupa nesvrstanih na najvišem nivou. ${ }^{55}$

${ }^{50}$ Isto.

51 DA MSP, PA, 1970, R, f-242, 435 836, Izveštaj o Trećoj konferenciji šefova država ili vlada nesvrstanih zemalja; DA MSP, 1970, PA, R, f-241, 432 028, Dokumentacija za Konferenciju na vrhu.

52 AJ, KPR, I-4-a/9. Nastavak generalne debate, Lusaka, 10. septembar 1970 (Bilten političkih informacija, br. 6).

53 AJ, KPR, I-4-a/9, Susreti Predsednika Republike sa šefovima delegacija nesvrstanih zemalja u Lusaki od 7. do 12. septembra 1970.

${ }^{54}$ DA MSP, PA, 1970, R, f-241, 432 028, Dokumentacija za Konferenciju na vrhu; AJ, KPR, I-4-a/9, Nastavak prepodnevne debate, Lusaka, 9. septembra 1970 (Bilten političkih informacija, br. 5).

${ }^{55}$ AJ, KPR, I-4-a/9, Bilteni političkih informacija o radu Konferencije. 
Ipak, i dalje je kod najvećeg broja nesvrstanih zemalja bila prisutna bojazan da bi uspostavljanjem jedne hijerarhijski ustrojene međunarodne asocijacije bio stvoren „treći blok“, što bi naišlo na oštru osudu svetske javnosti i u određenom smislu dovelo nesvrstane zemlje u situaciju da se podvrgavaju nekom novom centru odlučivanja. Stoga je i sam Tito, iako je u stvaranju stalnih mehanizama nesvrstanih zemalja video jedini način da se obezbedi kontinuirana i organizovana zajednička saradnja tih zemalja, ispoljavao određenu kritičnosti u vezi sa potrebom formiranja stalnog sekretarijata ili biroa. Strahovao je da bi u tom telu glavnu reč imale zemlja-domaćin i uža grupa nesvrstanih zemalja, dok bi ostale zemlje bile marginalizovane i svedene na pasivnog posmatrača. Jugoslovenski predsednik je tu osećao nekakav „prizvuk blokova“ i „blokovskog grupisanja“. Budući da je na neki način, ipak, bilo neophodno obezbediti određen stepen koordinacije i kontinuiteta aktivnosti nesvrstanih zemalja, Tito je sugerisao formiranje jednog „tehničkog“, ali ,ne i političkog tela“, koje bi preuzelo organizacione poslove. ${ }^{56}$ Jugoslovenski ministar inostranih poslova Mirko Tepavac je kasnije objašnjavao da $\mathrm{u}$ pogledu inicijative za obezbeđivanje kontinuiranog i trajnog delovanja nesvrstanih „kod nekih nismo naišli na razumevanje“ i da se zbog toga „nije smelo previše insistirati na tome, jer bi ispalo da Jugoslavija pokušava da se nametne kao nekakav sakupljač nesvrstanih, što bi opet stvorilo utisak da se ona pri tome rukovodi nekim užim, posebnim interesima“. ${ }^{57}$

Učesnici Samita u Lusaki su se na kraju saglasili da bi radi obezbeđivanja kontinuirane saradnje nesvrstanih trebalo obavezno obezbediti uslove za održavanje redovnih godišnjih sastanaka ministara inostranih poslova na kojima bi bili razmatrani aktuelni problemi i postignut dogovor o zajedničkom delovanju. ${ }^{58} \mathrm{Na}$ osnovu brojnih predloga učesnika Samita u Lusaki, postignut je dogovor o potrebnim merama koje bi vodile obezbeđivanju neophodnih uslova za kontinuirano i organizovano delovanje nesvrstanih u međunarodnim odnosima. $\mathrm{U}$ tu svrhu usvojena je posebna rezolucija u kojoj se insistiralo „na neophodnosti da se obezbedi kontinuitet i poveća efikasnost uloge nesvrstanih zemalja na taj način što će se putem odgovarajućih mehanizama osigurati izvršenje odluka, rezolucija i direktiva konferencije nesvrstanih zemalja“. Stoga je predsedniku Konferencije, kao koordinatoru, stavljeno u zadatak da uz pomoć generalnog sekretara preduzme korake ,za održavanje veze između država članica, osigura kontinuitet i ostvaruje odluke, rezolucije i direktive konferencije nesvrstanih zemalja“. Ovo su bile prve mere institucionalizacije saradnje nesvrstanih zemalja. Usvojenom Rezolucijom, u izvesnom smislu, stvoreni su uslovi za stvaranje prvog izvršnog organa nesvrstanih zemalja. ${ }^{59}$

${ }^{56}$ AJ, KPR, I-4-a/9, Razgovor predsednika Tita sa jugoslovenskim novinarima, Lusaka, 11. septembar 1970; Susreti i razgovori.

57 AJ, KPR, I-4-a/9, Izvod iz beleške o razgovorima članova jugoslovenske delegacije po završetku Konferencije u Lusaki, 10. septembra 1970.

${ }^{58}$ AJ, KPR, I-4-a/9, Susreti i razgovori.

${ }^{59}$ AJ, KPR, I-4-A/9, Rezolucija o jačanju uloge nesvrstanih zemalja. 
Od Konferencije u Lusaki, ideja o stvaranju tela ili organa koji će održavati kontinuitet zajedničkih aktivnosti, brinuti o sprovođenju odluka i obezbeđivati redovnija savetovanja bila je stalno na dnevnom redu svih skupova nesvrstanih zemalja. Posle ove konferencije postepeno su se sve više granali institucionalni oblici saradnje nesvrstanih zemalja, koji su im obezbeđivali sve veću prodornost i sve veći uticaj u sferi međunarodnih odnosa. To je bilo vreme kada se Pokret nesvrstanosti nametnuo kao važan i respektabilan međunarodni faktor, a nesvrstavanje postalo privlačna politička doktrina za većinu zemalja afroazijskog i latinoameričkog prostora.

\section{REFERENCE}

- Aćimović, Ljubivoje. Problemi bezbednosti u Evropi. Beograd: IMPP/Prosveta, 1978.

- Bogetić Olivera, i Dragan Bogetić. Nastanak i razvoj pokreta nesvrstanosti. Beograd: Export-press, 1981.

- Bogetić, Dragan. „Jugoslavija u Hladnom ratu“. Istorija 20. veka, god. XXVI, br. 2, (2008), 315-370.

- Bogetić, Dragan. Jugoslovensko-američki odnosi 1961-1971. Beograd: ISI, 2012.

- Bogetić, Dragan. „Kiparska kriza 1974. i pogoršanje jugoslovensko-američkih odnosa“". Tokovi istorije, br. 3, (2014), 111-129.

- Bogetić, Dragan. „Yugoslavia and Non-Alignment: a Contribution to Overcoming Prejudices and Stereotypes“. Annales, Series Historia et Sociologia, let. 24, br. 4 (2014), Koper 2014, 615-624.

- Čehulić Vukadinović, Lidija. Euroatlantizam i suvremeni međunarodni odnosi. Zagreb: Politička kultura, 2010.

- Godišnjak Instituta za međunarodnu politiku i privredu. 1970. Beograd: IMPP, 1971.

- Ivanović, Vladimir. Jugoslavija i SR Nemačka 1967-1973. Beograd: ISI, 2009.

- Jakovina, Tvrtko. „Tito's Yugoslavia as the Pivotal State of the Non-Aligned“. U: Tito - viđenja i tumačenja, Zbornik radova. Urednica Olga Manojlović Pintar, 389-404. Beograd: INIS, Arhiv Jugoslavije, 2011.

- Keesing's Contemporary Archives, 1970.

- Kreačić, Miroslav. „Značaj Konsultativnog sastanka specijalnih predstavnika vlada nesvrstanih za kontinuitet i razvoj pokreta nesvrstanosti“. U: Tito nesvrstanost - savremenost, Zbornik radova. Urednici Bojana Tadić, Vladimir Falatov, 87-93. Beograd: Memorijalni centar „Josip Broz Tito“, 1988.

- Mandić, Blažo. Tito u dijalogu sa svetom. Novi Sad: Mir/Prometej, 2005.

- Mates, Leo. Međunarodni odnosi socijalističke Jugoslavije. Beograd: Nolit, 1976.

- Mojsov, Lazar. „Savremena kriza međunarodnih odnosa i politika i pokret nesvrstanosti“. U: Tito - nesvrstanost - savremenost, Zbornik radova. Urednici Bojana Tadić, Vladimir Falatov, 175-193. Beograd: Memorijalni centar „Josip Broz Tito“, 1988.

- Radenković, Đorđe. Tito: susreti sa državnicima sveta. Beograd: Mladost, 1975. 
- Redžepagić, Sulejman (ur.). Radnički i nacionalno-oslobodilački pokreti. Tom I, Afrika, Azija, Latinska Amerika. Beograd: Institut za izučavanje radničkog pokreta, 1968.

- Stojković, Momir. Tito-Nehru-Naser - nastavak i razvoj politike i pokreta nesvrstanosti. Zaječar: „Zaječar“, 1983.

- Štaubringer, Zvonko. Maršal mira. Zagreb: Globus, 1980.

- Vukadinović, Radovan. Evropska sigurnost i suradnja. Zagreb: Globus, 1976.

DRAGAN BOGETIĆ, PhD, Principal Research Fellow

Institute of Contemporary History

Belgrade, Republic of Serbia

dbogetic@gmail.com

\section{CONTRIBUTION OF THE CONFERENCE IN LUSAKA 1970 TO THE INSTITUTIONALIZATION OF COOPERATION OF NON-ALIGNED COUN- TRIES AND THEIR REACTIVATION IN INTERNATIONAL RELATIONS}

\section{Summary}

During the 70-ies of the last century, non-aligned countries were undertaking initiatives for the formation of a wide movement. This movement was needed to provide conditions for their continuous and coordinated joint actions in international relations. The turning point in this context was the summit in Lusaka (capital of Zambia). There, for the first time, an agreement was finally reached on the measures that would result in the formation of the Non-Aligned Movement and that would contribute to strengthening the role of non-aligned countries in the United Nations and in the wider sphere of international relations. The countries that participated in the conference in Lusaka agreed that the Non-Aligned Movement must not assume the characteristics of a "third block“. It was supposed to represent a broad and open organization, devoid of any new centers of power and hierarchical organization. Hence, they rejected the suggestions of a group of non-aligned countries to form and solidify the Permanent Secretariat body, in which a decisive role would be played by the host country and a narrower group of the politically most exposed countries. After the conference in Lusaka came a period which was often referred to as the "golden age“ of non-alignment. This name seems appropriate, because this was a time of a sudden branching of institutional mechanisms of cooperation of Non-Aligned Countries and their increasingly widespread and powerful joint participation in international relations.

KEYWORDS: blocks, non-aligned countries, Yugoslavia, Zambia, Tito, decolonization, coordination, cooperation, Middle East, Far East 